\title{
Designing the training students methods of automated documents creation
}

\author{
Istomina $\mathbf{N}$. \\ Kremenchuk Mykhailo Ostrohradskyi National University, Kremenchuk, Ukraine
}

Received: $10.09 .2020 \quad$ Accepted: 25.09 .2020

\begin{abstract}
In modern conditions, informatization permeate into all spheres of society. This also applies to the educational sphere. At the moment, many software products are involved in the educational process. Involve of software products helps to increase the clarity and aesthetics of students' paperwork. At the same time, the dominance of technical means increases the student load. It should also be noted that the speed of paperwork is often reduced. Students spend more time on the results with the help of technical means than on the work done by hand. This contradiction can be resolved by students acquiring skills in working with automated documents. This work is devoted to the development of methods for training students the principles of creating automated documents through the use of automatic elements: styles, objects, labels, links, automatic lists of various directions. The theoretic, practical and individual stages are fixed in the developed method. The thematic plan with covering all parties of automatic elements application at document creation is designed. The main tools used to create an automated document in most of the software products used are highlighted. Chief among these tools are: labels, links, programmable fields. To work with documents, you can use many software products, among which the most common are Microsoft Office, LaTeX, Libre Office. Today, given the current trend of distributing free licenses of software products for educational institutions and education seekers, the Microsoft Office suite remains the most popular among students. Taking this into account, the work provides examples of the implementation of tasks that correspond to the compiled thematic plan using the means of the Microsoft Office package. All examples are accompanied by pictures explaining the use of the selected automatic element. As a result of the work, a method for training students the principles of creating automated documents was formulated. Implementation of the designed training method allows to reduce the time spent on preparing an electronic document, improve the documents design quality and increase the flexibility of the received content for export, import and editing operations.

Key words: training, methods, practical skills, automated documents, automatic document design elements.
\end{abstract}

\section{Розробка методики навчання студентів створенню автоматизованих документів}

\author{
Істоміна Н. М.
}

Кременчуцький національний університет імені Михайла Остроградського, Кременчук, Україна

\begin{abstract}
Анотація. В сучасних умовах інфоорматизація проникає в усі ссрери суспільства. Це також стосується $\mathrm{i}$ освітньої сфери. У навчальний процес на поточний момент залучено безліч програмних продуктів, які допомагають підвищити наочність та естетичність оформлення документів студентами. Водночас засилля технічних засобів збільшує навантаження на студента. Також слід відмітити, що швидкість офоормлення документів найчастіше при цьому знижується. На оформлення результатів із залученням технічних засобів студенти витрачають більше часу, ніж на роботи виконані вручну. Вирішити цю суперечність можна за допомогою набуття студентами навичок роботи з автоматизованими документами. Дана робота присвячена розробці методики навчання студентів принципам створення автоматизованих документів, за допомогою використання автоматичних елементів: стилів, об'єктів, міток, посилань, автоматичних переліків різної направленості. У розробленій методиці закріплені теоретичний, практичній та індивідуальний етапи. Розписаний тематичний план, який охоплює всі сторони застосування автоматичних елементів при створенні документа. Виділені основні засоби, які використовуються для створення автоматизованого документу у більшості застосованих програмних продуктів. Головними серед цих засобів є: закладки, посилання,
\end{abstract}

\footnotetext{
Corresponding Author: Istomina Nataliia Mykolaivna. Tel. +38(05366) 3-11-47. E-mail: nmistomina@gmail.com Kremenchuk Mykhailo Ostrohradskyi National University, vul. Pershotravneva, 20, Kremenchuk, Poltava Region, Ukraine, 39600.

Biдnовідальний автор: Істоміна Наталія Миколаївна. Тел. +38(05366) 3-11-47. E-mail: nmistomina@gmail.com Кременчуцький національний університет імені Михайла Остроградського, вул. Першотравнева, 20, м. Кременчук Полтавської обл., Україна, 39600.
} 
програмовані поля. Для роботи з документами можна застосовувати багато програмних продуктів, серед яких найпоширенішими $є$ Microsoft Office, Latex, Libre Office. На сьогоднішній день, з огляду на сучасну тенденцію розповсюдження безкоштовних ліцензій програмних продуктів для навчальних закладів та здобувачів освіти, найпопулярнішим серед студентів залишається пакет Microsoft Office. 3 огляду на це в роботі наведені приклади реалізації завдань, які відповідають складеному тематичному плану, засобами пакету Microsoft Office. Всі приклади супроводжуються зображеннями з поясненнями щодо використання вибраного автоматичного елементу. В результаті роботи сформульована методика навчання студентів принципам створення автоматизованих документів, яка дозволить зменшити час витрачений на підготовку електронного документа, підвищити якість його оформлення та підвищити гнучкість отриманого контенту до операцій експорту, імпорту та редагування.

Ключові слова: навчання, методика, практичні навички, автоматизовані документи, автоматичні елементи оформлення документа.

\title{
Разработка методики обучения студентов созданию автоматизированных документов
}

\author{
Истомина Н. Н. \\ Кременчугский национальный университет имени Михаила Остроградского, Кременчуг, Украина
}

\begin{abstract}
Аннотация. В современных условиях информатизация проникает во все сферы общества. Это также касается и образовательной сфреры. В учебный процесс на текущий момент привлечено множество программных продуктов, которые помогают повысить наглядность и эстетичность оформления документов студентами. В то же время засилье технических средств увеличивает нагрузку на студента. Также следует отметить, что скорость оформления документов чаще всего при этом снижается. На офоормление результатов с привлечением технических средств студенты тратят больше времени, чем на работы выполнены вручную. Решить это противоречие можно с помощью приобретения студентами навыков работы с автоматизированными документами. Данная работа посвящена разработке методики обучения студентов принципам создания автоматизированных документов, посредством использования автоматических элементов: стилей, объектов, меток, ссылок, автоматических списков различной направленности. В разработанной методике закреплены теоретический, практический и индивидуальный этапы. Расписан тематический план, который охватывает все стороны применения автоматических элементов при создании документа. Выделены основные средства, используемые для создания автоматизированного документа в большинстве применяемых программных продуктов. Главными среди этих средств являются: закладки, ссылки, программируемые поля. Для работы с документами можно использовать множество программных продуктов, среди которых наиболее распространены Microsoft Office, LaTeX, Libre Office. Ha сегодняшний день, учитывая современную тенденцию распространения бесплатных лицензий программных продуктов для учебных заведений и соискателей образования, самым популярным среди студентов остается пакет Microsoft Office. Учитывая это в работе приведены примеры реализации задач, которые соответствуют составленному тематическому плану, средствами пакета Microsoft Office. Bce примеры сопровождаются изображениями с пояснениями по использованию выбранного автоматического элемента. В результате работы сфрормулирована методика обучения студентов принципам создания автоматизированных документов, которая позволит уменьшить время, затраченное на подготовку электронного документа, повысить качество его оформления и повысить гибкость полученного контента к операциям экспорта, импорта и редактирования.
\end{abstract}

Ключевые слова: обучение, методика, практические навыки, автоматизированные документы, автоматические элементы оформления документа.

\section{Bcmyn}

У реаліях сьогодення всі здобувачі вищої освіти багато часу приділяють оформленню різних видів електронних документів:

- оформлення звітів з лабораторних, практичних, семінарських занять;

- написання ресрератів, інформаційних повідомлень;

- ведення конспектів лекцій;

- підготовка доповідей, презентацій;

- оформлення результатів досліджень на задану тематику (студентські наукові роботи, звіти з науково-дослідної роботи, курсові роботи і проекти, дипломні роботи і проекти). 
При цьому для оформлення в якості інструментів використовуються різні програмні продукти. Ступінь залучення цих інструментів оформлення визначається корисністю, легкістю в освоєнні, і доступністю (нажаль велика кількість програмних продуктів залишається платними і немає механізмів оформлення вільного користування для студентів). Тому в даній роботі ми обмежені в першу чергу програмними продуктами, які наявні у вільному доступі або ліцензії на які, наявні у власності 3ВО.

Але не залежно від виду використовуваного інструменту існують вимоги, яких необхідно дотримуватись при оформленні документа $[1,2]$. Роботи $[3,4]$ розглядають не лише вимоги до оформлення документів, але й еволюцію цих вимог.

Перелік цих вимог залежить від типу створюваного документу та крім естетичних, до найбільш використовуваних належать [5]:

- ДСТУ 4163-2003. Вимоги до оформлювання документів;

- ДСТУ 4163:20. Державна уніфрікована система документації. Уніфікована система організаційно-розпорядчої документації;

- ДСТУ 3017-95. Видання. Основні види: Терміни та визначення;

- ДСТУ 3018-95. Видання. Поліграффічне виконання;

- ДСТУ 3772-98. Оригінали для поліграфічного відтворення: Загальні технічні вимоги;

- ДСТУ 3814-98. Видання. Міжнародна стандартна нумерація книг;

- ДСТУ 2938-94. Системи оброблення інформації. Основні поняття: Терміни та визначення;

- ДСТУ 3008-95. Документація. Звіти у сфрері науки і техніки: структура і правила оформлення;

- ДСТУ 3146-95. Штрихове кодування. Маркування об'єктів ідентифрікації. Штрихові позначки ЕАN/Вимоги до побудови;

- ДСТУ 3359-96. Коди та кодування інформації. Штрихове кодування. Маркування об'єктів ідентифікації. Якість друку штрих-кодових позначок. Загальні технічні вимоги та методи контролю;

- ДСТУ 3582-97. Скорочення слів в українській мові у бібліографічному описі: Загальні вимоги та правила;

- ДСТУ 2394-94. Інформація та документація. Комплектування фонду, бібліографічний опис, аналіз документів: Терміни та визначення;

- ДСТУ ГОСТ 7.1:2006 Система стандартів з інформації, бібліотечної та видавничої справи. Бібліографрічний запис. Бібліографічний опис. Загальні вимоги та правила;

- ДСТУ ГОСТ 7.80:2007 Система стандартів з інформації, бібліотечної та видавничої справи. Бібліографічний запис. Заголовок. Загальні вимоги та правила;

- ДСТУ 8302:2015 Інформація та документація. Бібліографічне посилання. Загальні положення та правила складання;

- ДСТУ 3582:2013 Інформація та документація. Бібліографічний опис. Скорочення слів і словосполучень в українській мові. Загальні вимоги та правила.

Звичайно на практиці студенти не користуються наведеними вище ДСТУ як першоджерелами, щодо вимог до оформлення документів. Здебільшого вони користуються документами більш низького порядку, тобто методичними рекомендаціями до оформлення підготовленими викладачами кафедр. Викладачі у свої чергу, користуються в першу чергу «Рукописом авторським. Основні вимоги щодо оформлення. Стандарт КрНУ». Для студентів найбільш зручно користуватись не просто правилами оформлення, а наочними прикладами. Окрім наявності наочних прикладів, також слід прививати студентам навички створення документів 3 автоматичними елементами, які апріорі полегшують створення наукової документації. Крім того за вимогами сучасного інформаційного простору всі документи мають визначені обов'язкові інформативні елементи, які спрощують обробку та індексування документів у реферативних, науко-метричних базах $[6,7,8]$. Для створення таких обов'язкових інформативних елементів також зручно використовувати автоматичні елементи документа. Тому актуальною задачею являється розробка методики навчання студентів оформленню наукової документації з використанням автоматичних елементів.

Mema роботи: підвищення ефективності навчання студентів шляхом прискорення оформлення електронних варіантів документів при використанні автоматичних елементів оформлення. 


\section{II Матеріал і методи дослідження}

В основі розроблюваної методики навчання лежить використання автоматичних елементів для підвищення якості та швидкості оформлення більшості документів, необхідних студентові у навчальному процесі (рис. 1). Документами, в яких найбільше залучені автоматичні елементи являються випускна робота та наукова стаття.

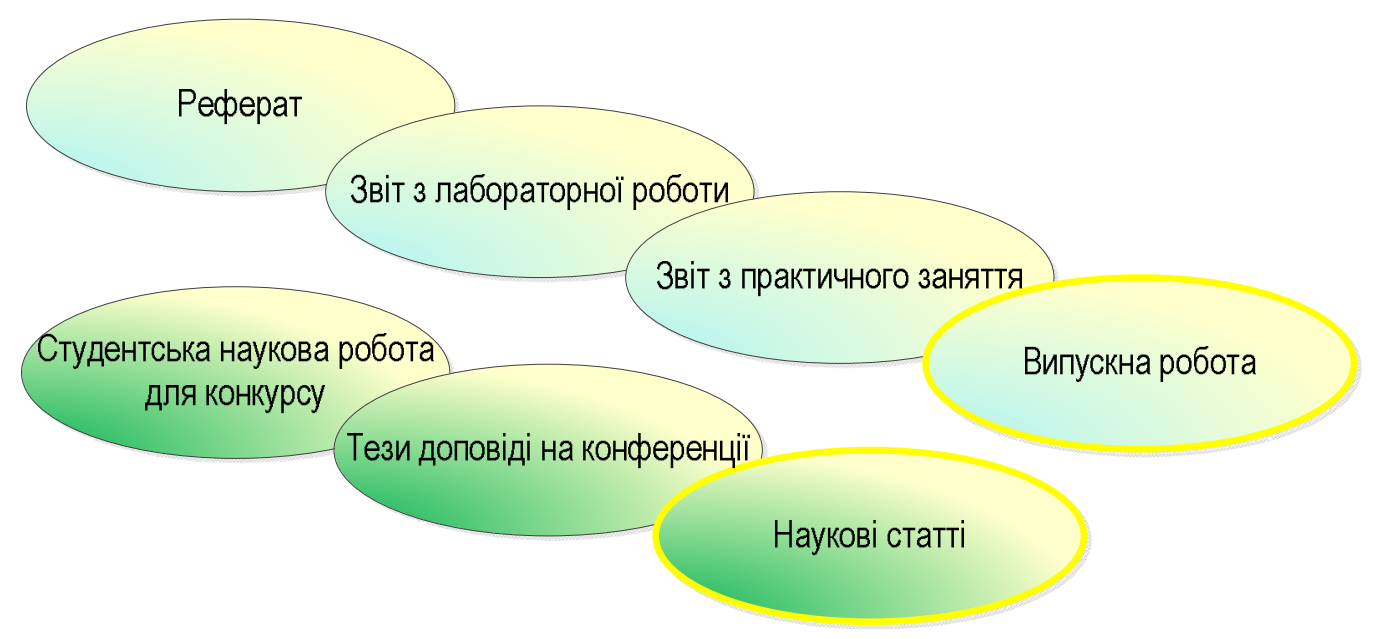

Рис. 1. Перелік основних документів, оформленням яких займається студент

Не враховуючи тип інструмента, який використовується, можна виділити наступні автоматичні елементи офрормлення:

- нумерація сторінок;

- верхній та нижній колонтитули;

- нумерація рисунків, таблиць, формул;

- автоматичний зміст;

- перелік використаних джерел;

- автоматичні посилання на рисунки, таблиці, формули, джерела;

- автоматично обчислювані формули;

- алфавітний покажчик.

Перелічені автоматичні елементи реалізуються за допомогою наступних засобів:

- мітки (закладки);

- посилання;

- стилі;

- автоматичні поля документа (маються на увазі елементи, які отримуються за допомогою функції «вставити поле»);

- розриви сторінок;

- налаштування шаблону.

Пропонуємо застосовувати наступну методику:

Eman 1 (теоретичний). Пояснення викладача щодо сутності автоматичного елементу, мети його використання, способу його реалізації.

Eman 2 (практичний). Демонстрація прикладу покрокової реалізації автоматичного елемента, одночасно з виконанням цих кроків студентами.

Eman 3 (індивідуальний). Виконання студентами самостійного завдання зі створення автоматичного елемента.

При цьому курс навчання використання автоматичних елементів послідовно складається 3 таких розділів та підрозділів: 
1. Налаштування шаблону програмного продукту.

1.1. Налаштування мови інтерфейсу, мови перевірки орфографрії за замовчуванням.

1.2. Налаштування границь тексту.

1.3. Налаштування параметрів імпорту/експорту тексту.

1.4. Налаштування додаткових інструментів (залежить від виду програмного продукту).

1.5. Налаштування авто-збереження.

2. Налаштування шаблону документа.

2.1. Відступи від краю сторінки (налаштування за замовченням).

2.2. Використання розривів сторінок та розділів.

2.3. Автоматична нумерація сторінок.

2.4. Фон сторінки.

2.5. Налаштування верхнього та нижнього колонтитулів.

3. Налаштування стилів тексту у документі.

3.1. Налаштування авто-оновлення стилів.

3.2. Налаштування основного стилю.

3.3. Налаштування стилів заголовків.

3.4. Налаштування стилів назви об'єкту.

4. Створення автоматичного змісту.

4.1. Збірка автоматичного змісту, грунтуючись на стилях заголовків.

4.2. Оновлення автоматичного змісту.

4.3. Налаштування зовнішнього вигляду пунктів автоматичного змісту.

4.4. Використання ключів-опцій при створенні автоматичного змісту.

4.5. Створення посилань на пункти автоматичного змісту за текстом.

5. Використання назви об'єкту з автоматичною нумерацією.

5.1. Створення автоматичної назви об'єкту типу «Рисунок».

5.2. Створення автоматичної назви об'єкту типу «Формула».

5.3. Створення автоматичної назви об'єкту типу «Таблиця».

5.4. Створення переліку ілюстрацій.

5.5. Створення автооновлюваних посилань на нумерацію різних типів назви об'єкту.

6. Створення переліку використаної літератури.

6.1. Створення автоматичної назви об'єкту типу «Джерело».

6.2. Створення автооновлюваних посилань на номера джерел із переліку використаної літератури.

6.3. Використання «Керування джерелами» (за наявності у програмному продукті).

6.4. Застосовні стилі оформлення бібліографічних посилань, рекомендовані МОН України.

6.5. Порівняння стилів оформлення ДСТУ 8302:2015, Harvard, APA.

7. Створення переліку умовних позначень.

7.1. Завдання елементів алфавітного покажчика.

7.2. Створення автоматичного алфавітного покажчика.

7.3. Використання таблиці посилань (за наявності у програмному продукті)

8. Використання автоматично обчислюваних формул у документі.

8.1. Сумування числових даних у стовпці/рядку.

8.2. Обчислення загального числа сторінок у документі, числа сторінок у розділі.

8.3. Обчислення загальної кількості рисунків, таблиць, формул.

8.4. Обчислення кількості умовних друкованих аркушів.

8.5. Обчислення алгебраїчних формул.

Курс навчання обов'язково повинен завершуватись контрольним завданням зі створення або форматування документа з використання всіх вивчених автоматичних елементів.

На теренах України для створення документів найчастіше використовують наступні програмні продукти: пакет Microsoft Office, Latex, Libre Office.

В період з 2010 по 2019 рік Libre Office набув все більшої популярності [9, 10]: головна причина цього полягала у безкоштовності даного сервісу на відміну від пакету Microsoft Office [11]. Ця ситуація 
змінилася у 2019 році з виходом пропозиції від компанії Microsoft, яка має назву Microsoft 365 [12], і представляє собою набір веб-сервісів (з підтримкою пристроїв з операційною системою Android), i на теренах України для викладачів 3ВО та студентів розповсюджується за безкоштовною ліцензією.

У великій кількості робіт обірунтовані переваги застосування Latex [13, 14, 15]. Нажаль набуття навичок роботи з пакетом Latex вимагає докладання багатьох зусиль. Особливі труднощі виникають у студентів гуманітарної направленості, оскільки робота з Latex потребує звички до програмування та алгоритмічної побудови структури документа [16, 17]. Office.

Тому, при формуванні практичних навичок, ми зосередимо увагу на застосуванні пакету Microsoft

\section{III Результати}

Розглянемо деякі приклади застосування автоматичних елементів форматування документу згідно з запропонованою методикою.

Налаштування шаблону програмного продукту.

Роботу з будь-яким програмним продуктом слід розпочинати з налаштування його інтерфейсу під власні потреби. За можливості необхідно налаштувати мову інтерфейсу. Обов'язково слід вказати мову перевірки орфографії за замовчуванням (рис. 2).

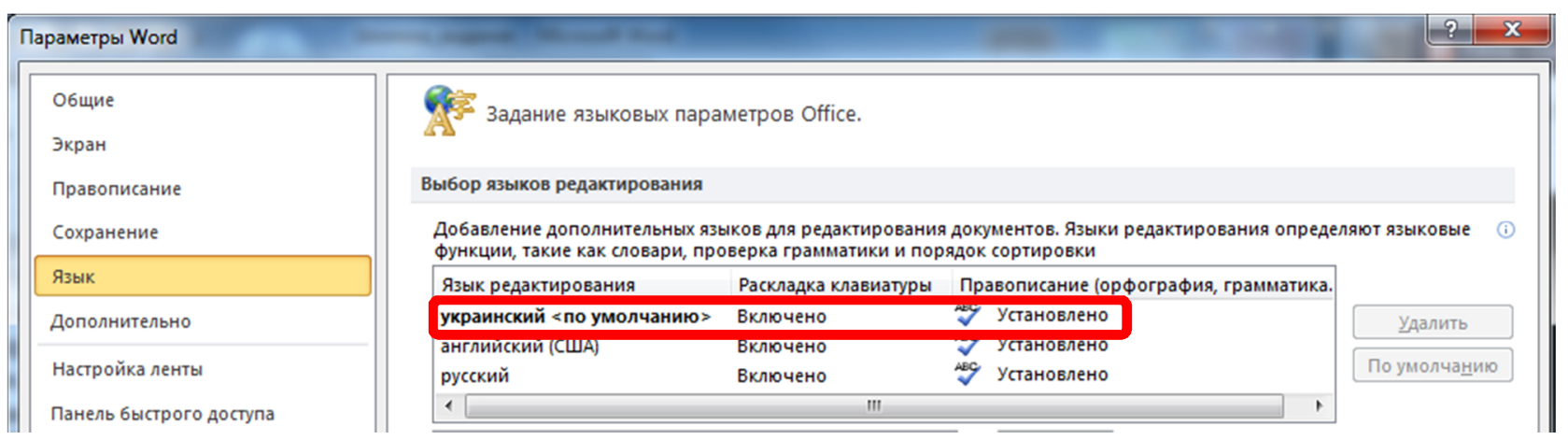

Рис. 2. Налаштування мови перевірки орфографрії за замовчуванням

Також ми пропонуємо змінити час автозберігання на 5 хвилин, а також змінити розташування папки для зберігання документів, бажано на диск, який не є системним (рис. 3).

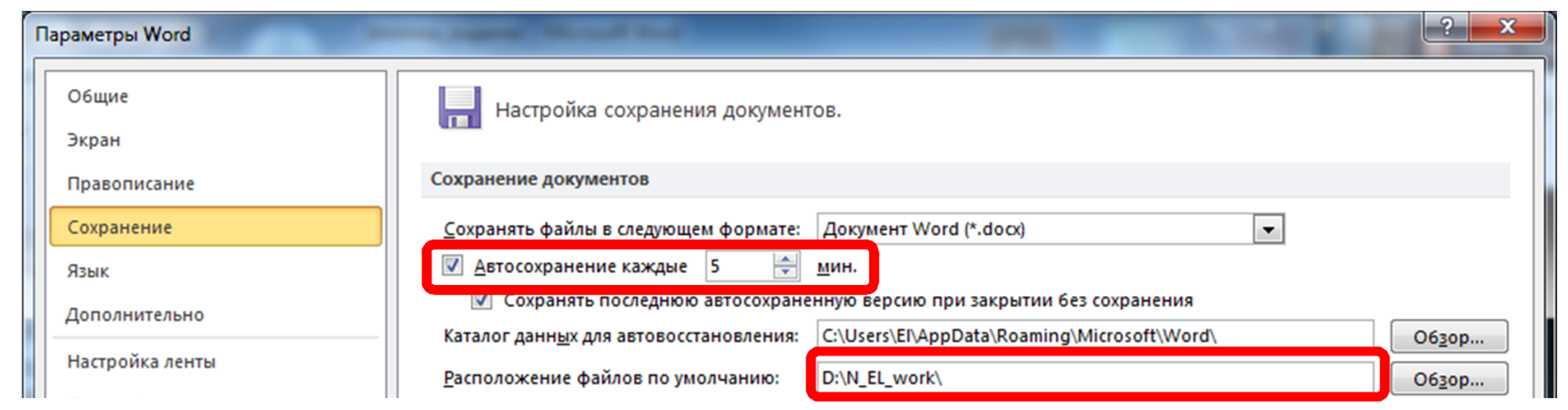

Рис. 3. Налаштування автозберігання документа

Серед додаткових налаштувань слід відобразити границі тексту (рис. 4), а також на панель швидкого доступу винести засоби, які Ви використовуєте найчастіше та які відсутні в основних меню (рис. 5): наприклад, вставити об'єкт, вставити поле, обрізка, додати перехресне посилання, статистика, мова перевірки правопису. 


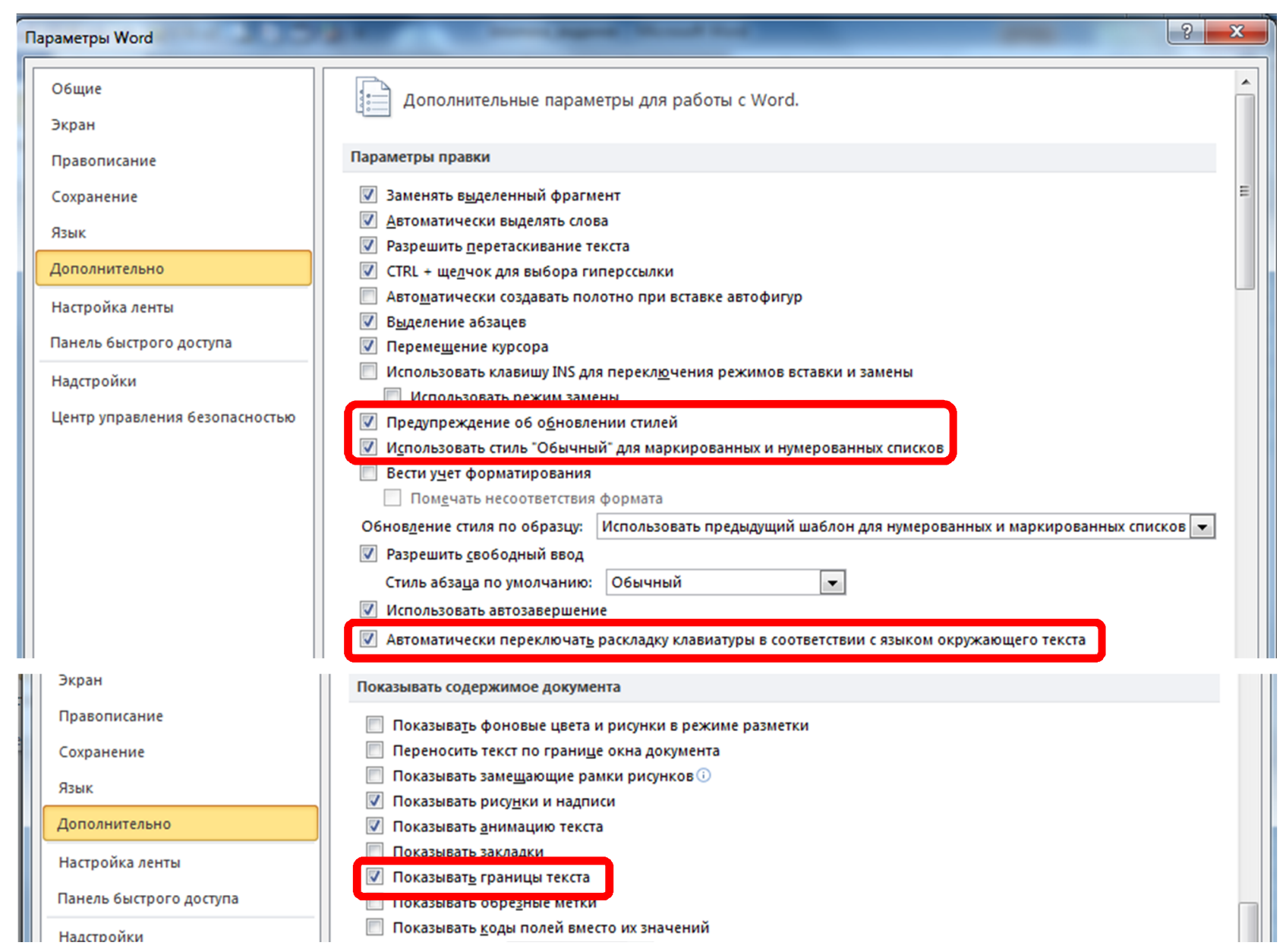

Рис. 4. Додаткові налаштування

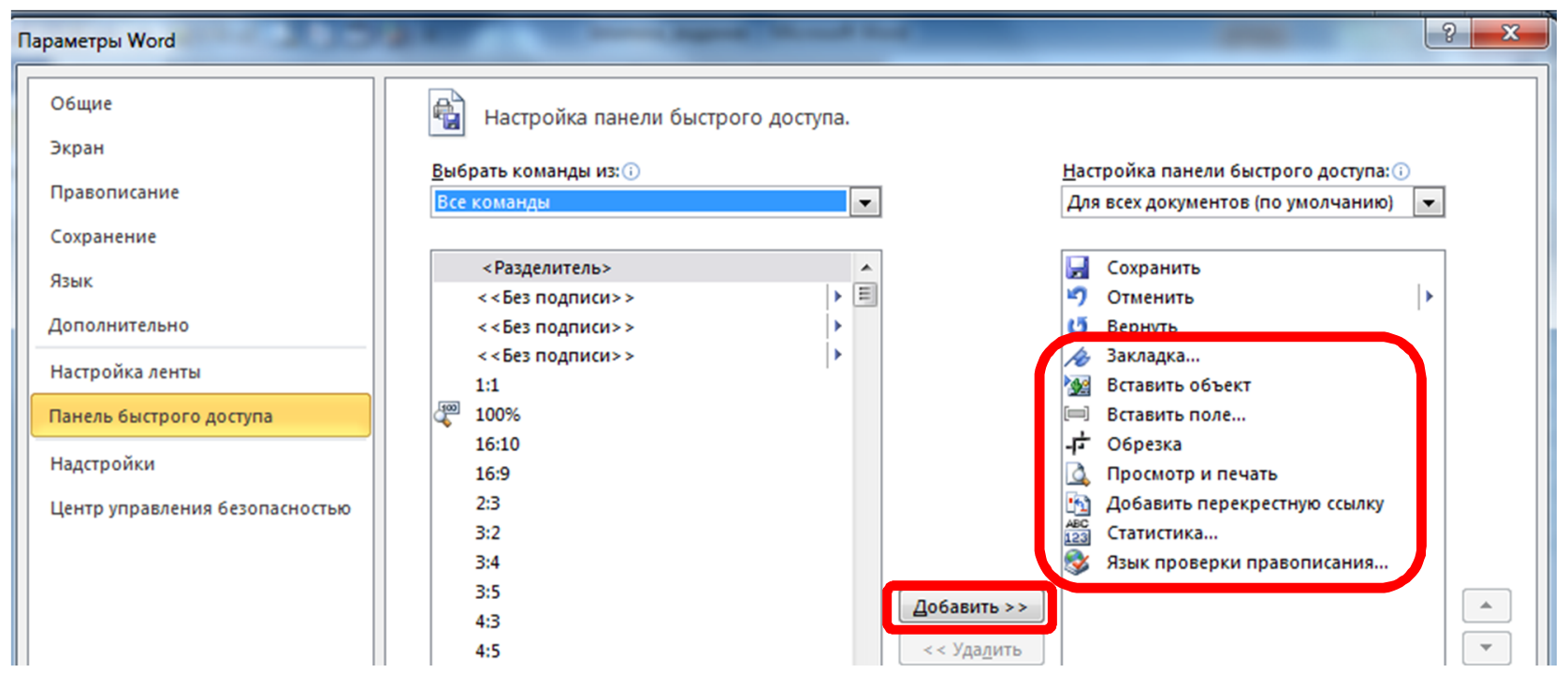

Рис. 5. Налаштування панелі швидкого доступу

\section{Налаштування шаблону документа.}

В першу чергу потрібно налаштувати відступи від країв сторінки, а також за необхідності дзеркальні поля або застосування різних колонтитулів для першої або парних/непарних сторінок (рис. 6), задати нумерацію сторінок (рис. 7). 


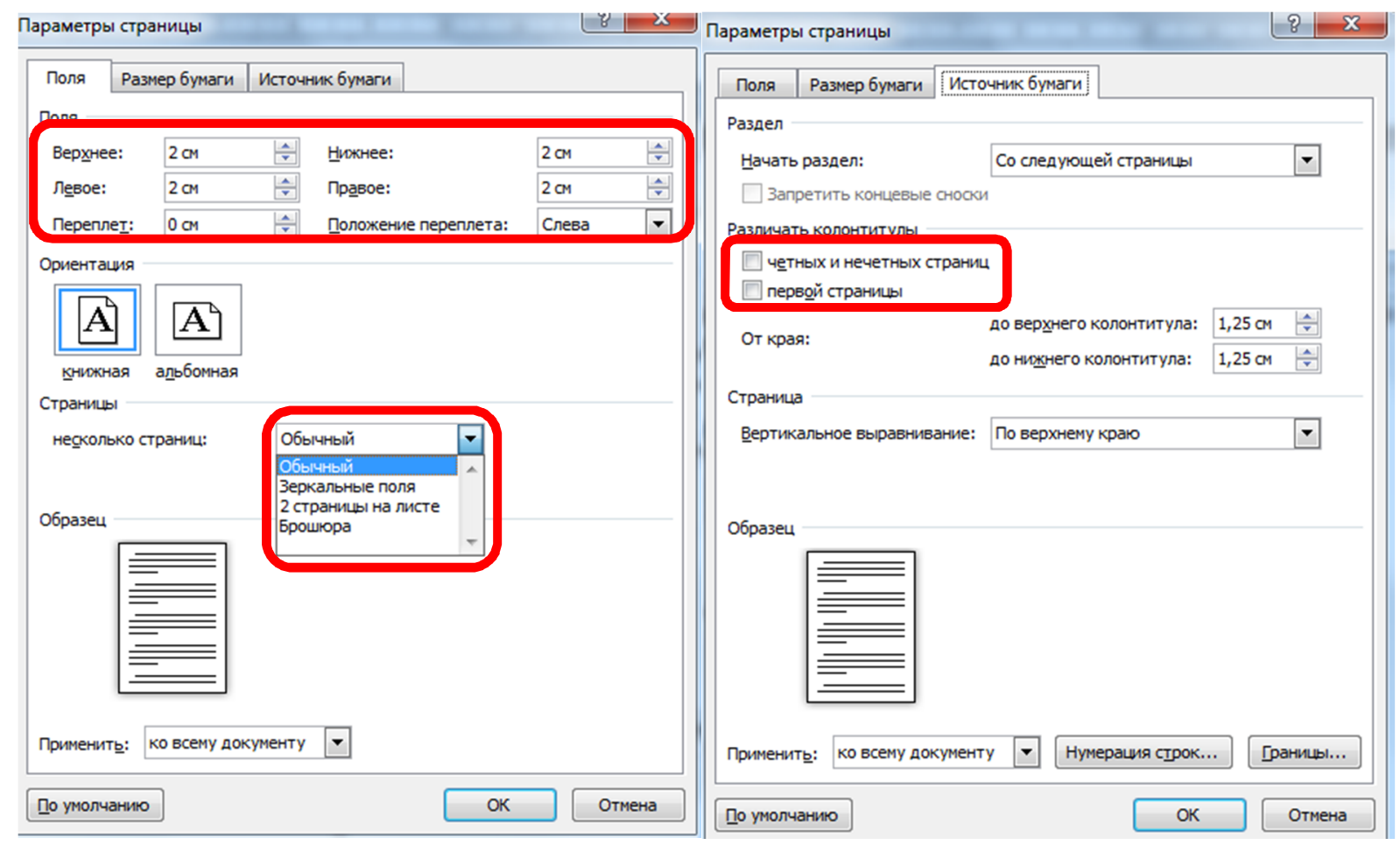

Рис. 6. Налаштування параметрів сторінки

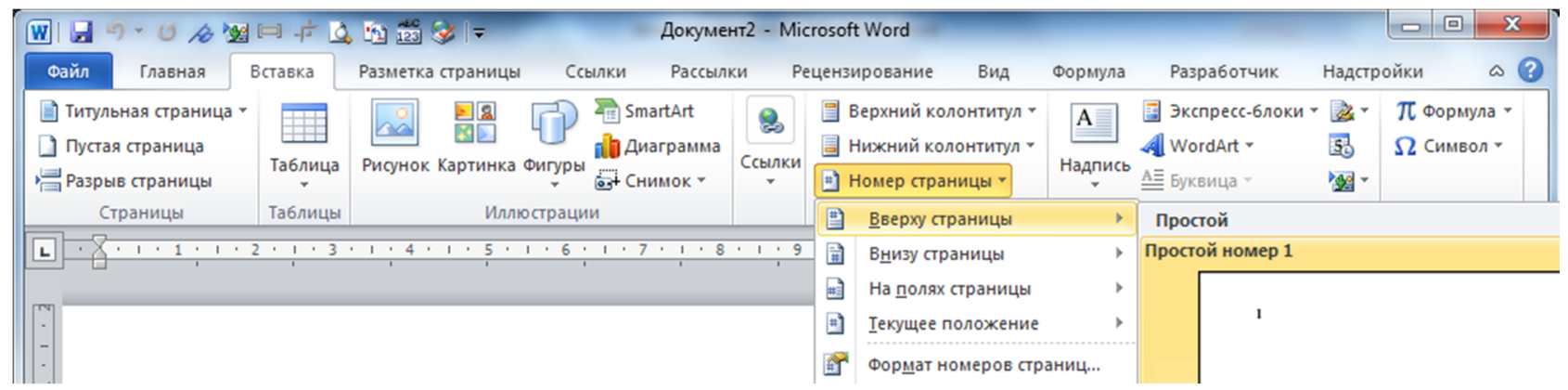

Рис. 7. Налаштування нумерації сторінок

Налаштування стилів тексту у документі.

Всі документи ірунтуються на використанні стилів. За замовчуванням використовується стиль «звичайний». Для забезпечення автоматичного змісту і посилань на розділи слід використовувати силі заголовків (рис. 8).

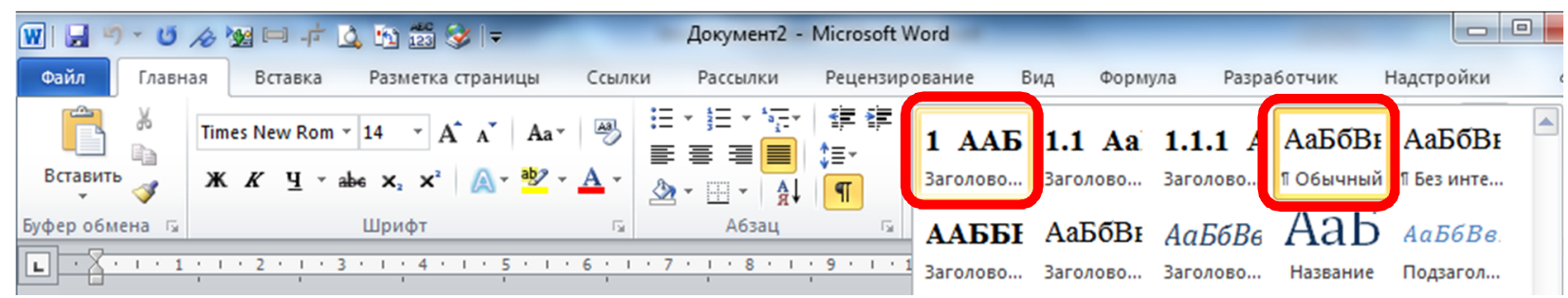

Рис. 8. Лінійка стилів документа

Всі стилі краще налаштовувати через опцію «Змінити», яка викликається правим кліком мишки. Тоді відкривається меню налаштування стилю (рис. 9). 


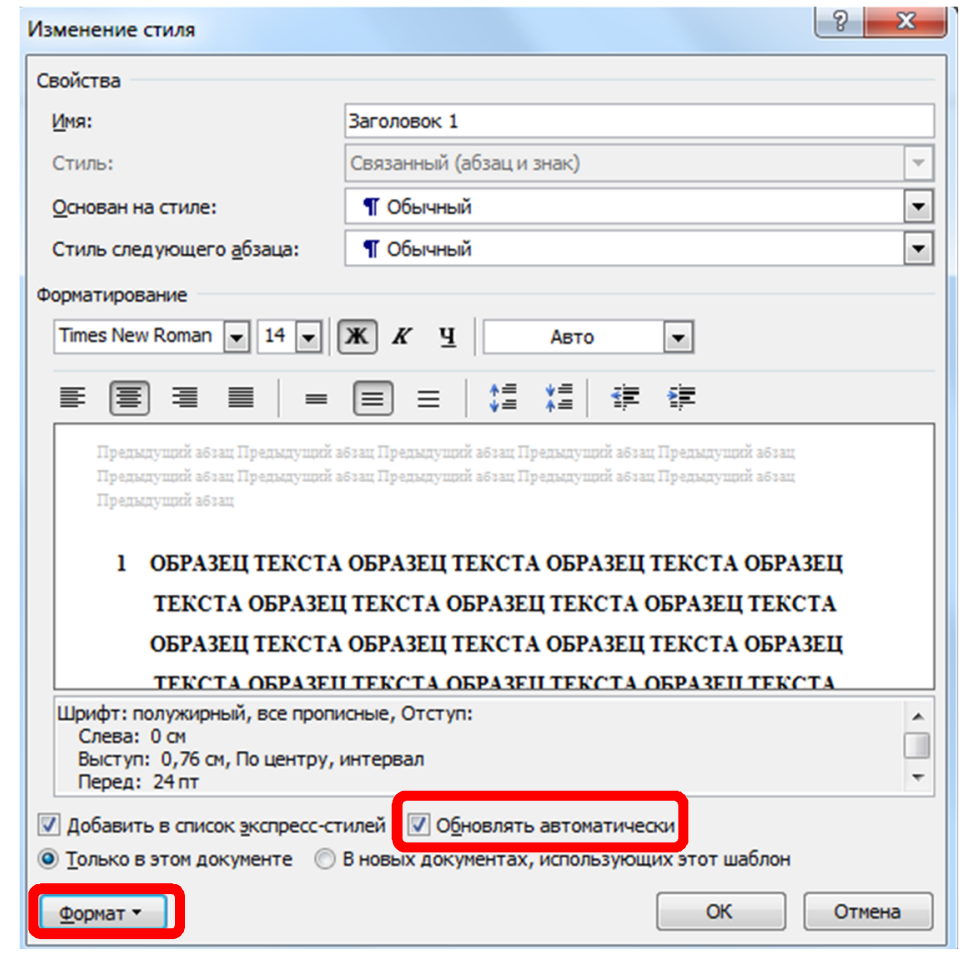

Рис. 9. Вікно налаштування стилю

Для налаштування краще використовувати меню «Формат». Слід також звертати увагу на опцію «Оновлювати автоматично»: для заголовків ця опція обов'язково повинна бути підключена, а для стилю «звичайний» обов'язково відключена (інакше текст по всьому документу буде автоматично змінюватись після форматування будь-якої його частини).

Створення автоматичного змісту.

Автоматичний зміст формується за допомогою підпункту «Зміст» меню «Посилання». Можна використовувати пропоновані стилі змісту, але краще налаштувати свій власний стиль змісту через виклик вікна налаштування змісту (рис. 10). У цьому вікні можна налаштувати символ-заповнювач до номеру сторінки, задати кількість рівнів змісту, а також відформатувати зовнішній вигляд всіх пунктів змісту.

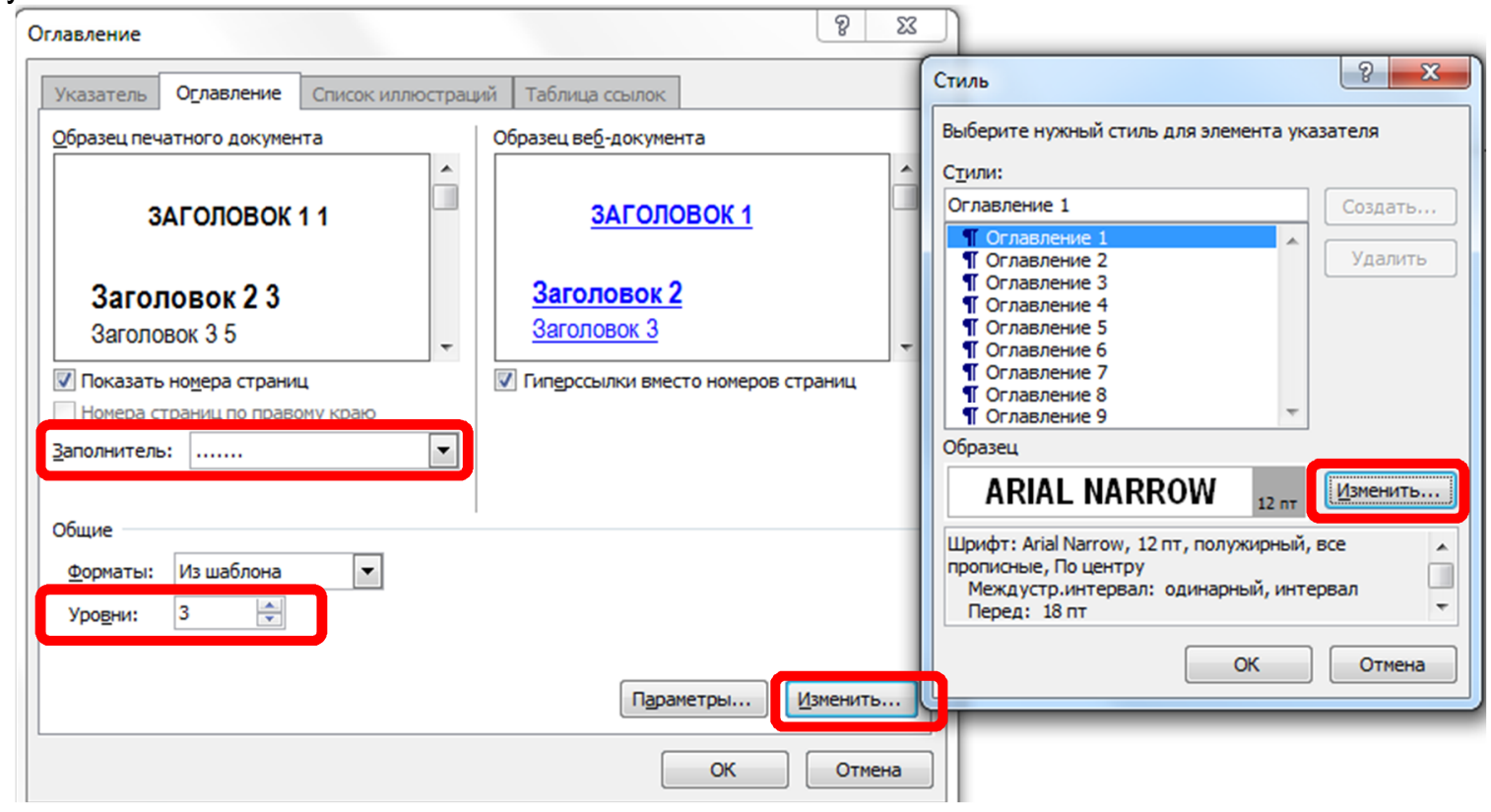

Рис. 10. Вікно налаштування змісту 
Використання назви об'єкту з автоматичною нумерацією.

Для нумерації рисунків, таблиць, формул та джерел із переліку використаної літератури краще використовувати назву об'єкта (рис. 11).

Існують вбудовані назви об'єктів, та можливість створювати власні назви об'єктів (рис. 12).

Головна перевага використання назв об'єктів полягає в їх автоматичній нумерації. Нумерація може бути простою, або включати номер заголовка (рис. 13).

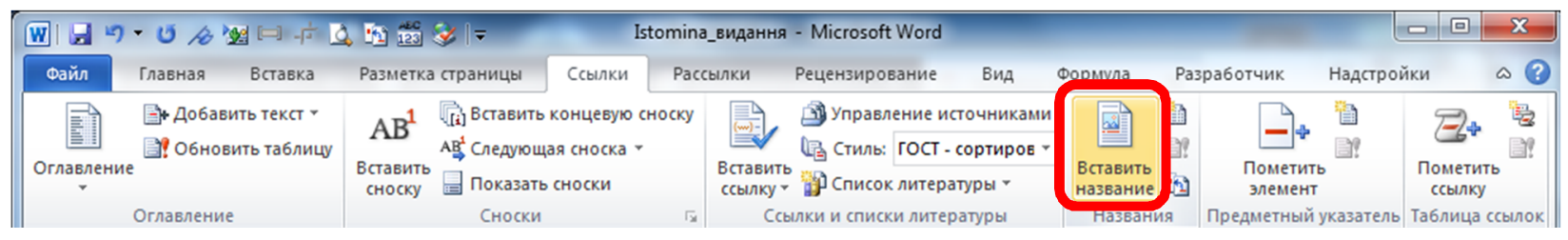

Рис. 11. Вставка назви об'єкту

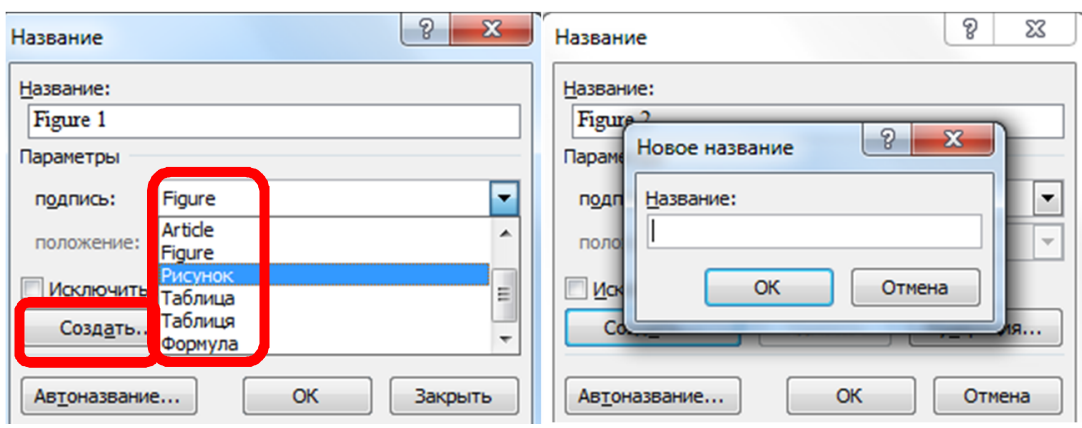

Рис. 12. Вставка назви об'єкту

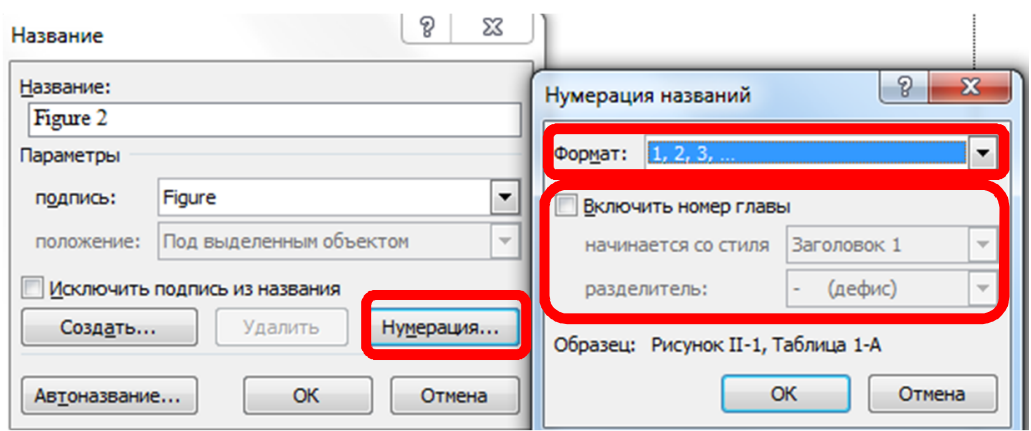

Рис. 13. Налаштування нумерації об'єкту

Створення автооновлюваних посилань на різні типи об'єктів.

Механізм створення таких посилань однаковий для всіх типів об'єктів. Використовуються два засоби: закладка та перехресне посилання (рис. 14).

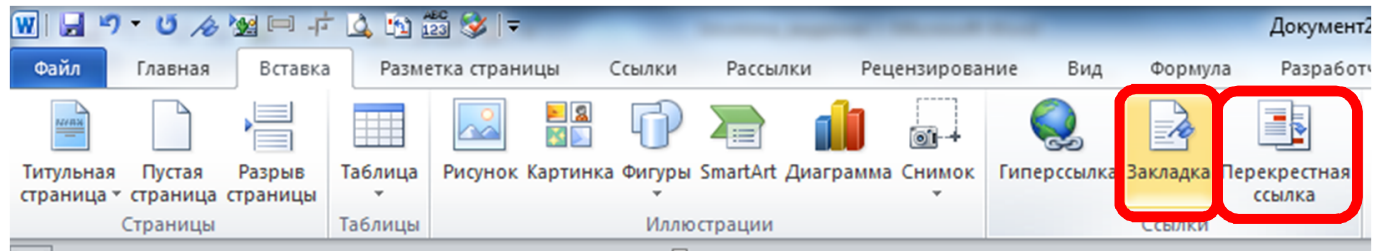

Рис. 14. Вставка закладок та перехресних посилань 
При створені закладки слід дотримуватись простих правил (рис. 15): назва закладки повинна характеризувати тип об'єкта (рис, табл тощо); повинна містити змістовну назву об'єкта; при написанні назви не можна використовувати проміжки.

По тексту вставляємо перехресне посилання на створену закладку (рис. 16).

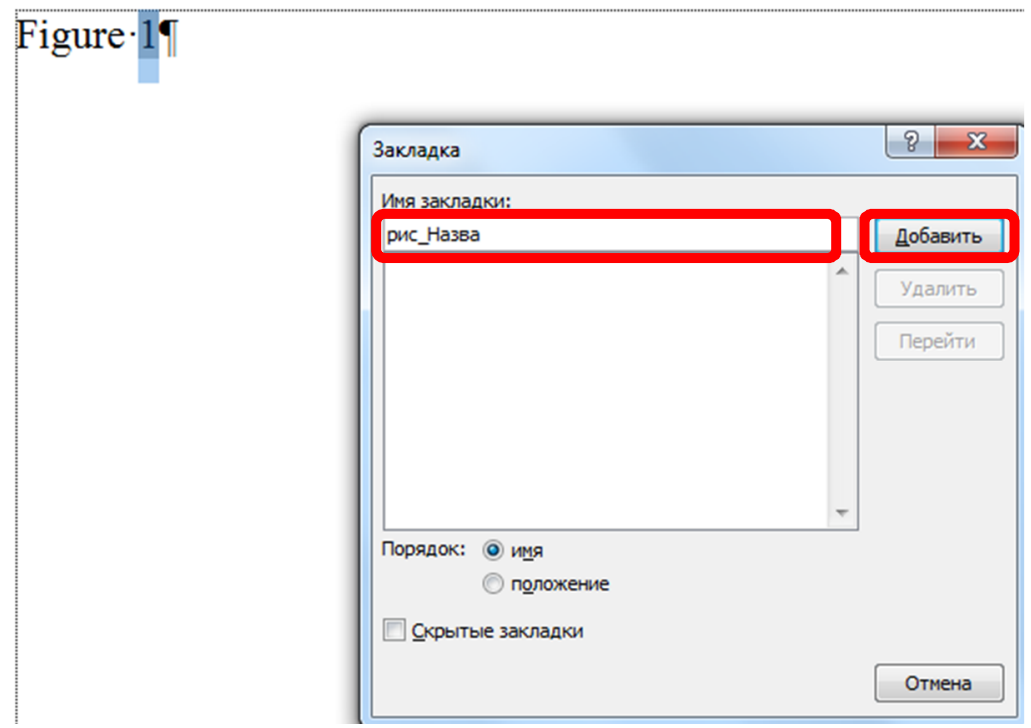

Рис. 15. Вставка закладки на номер рисунку

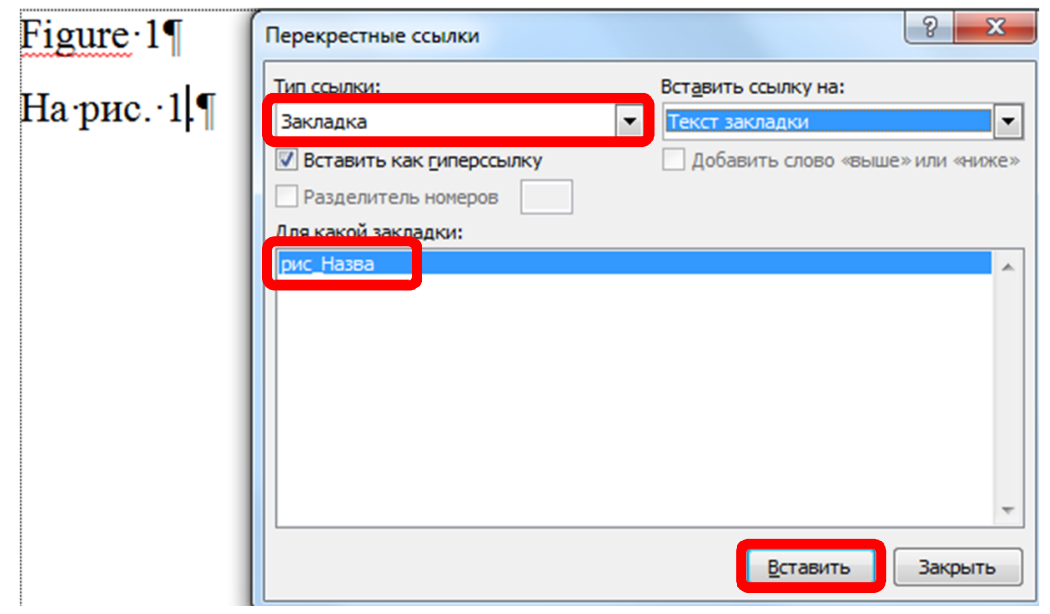

Рис. 16. Вставка закладки на номер рисунку

Використання автоматично обчислюваних формул у документі.

За допомогою команди «Вставить поле» можна вирішувати багато задач. Наприклад вставити загальну кількість сторінок в документі, як показано на рисунку 17. Зазначимо основні поля, які можна використовувати у документі:

- AutoNumLgl (вставка автоматичного номера, доступний вивід номера без точки);

- Bibliography (вставка переліку бібліографрічних посилань);

- CreateDate (вставка дати створення документа);

- Date (вставка поточної дати);

- EditTime (вставка загального часу витраченого редагування документа);

- SectionPages (вставка кількості сторінок у розділі);

- =(Formula) (вставка обчислюваної формули). 


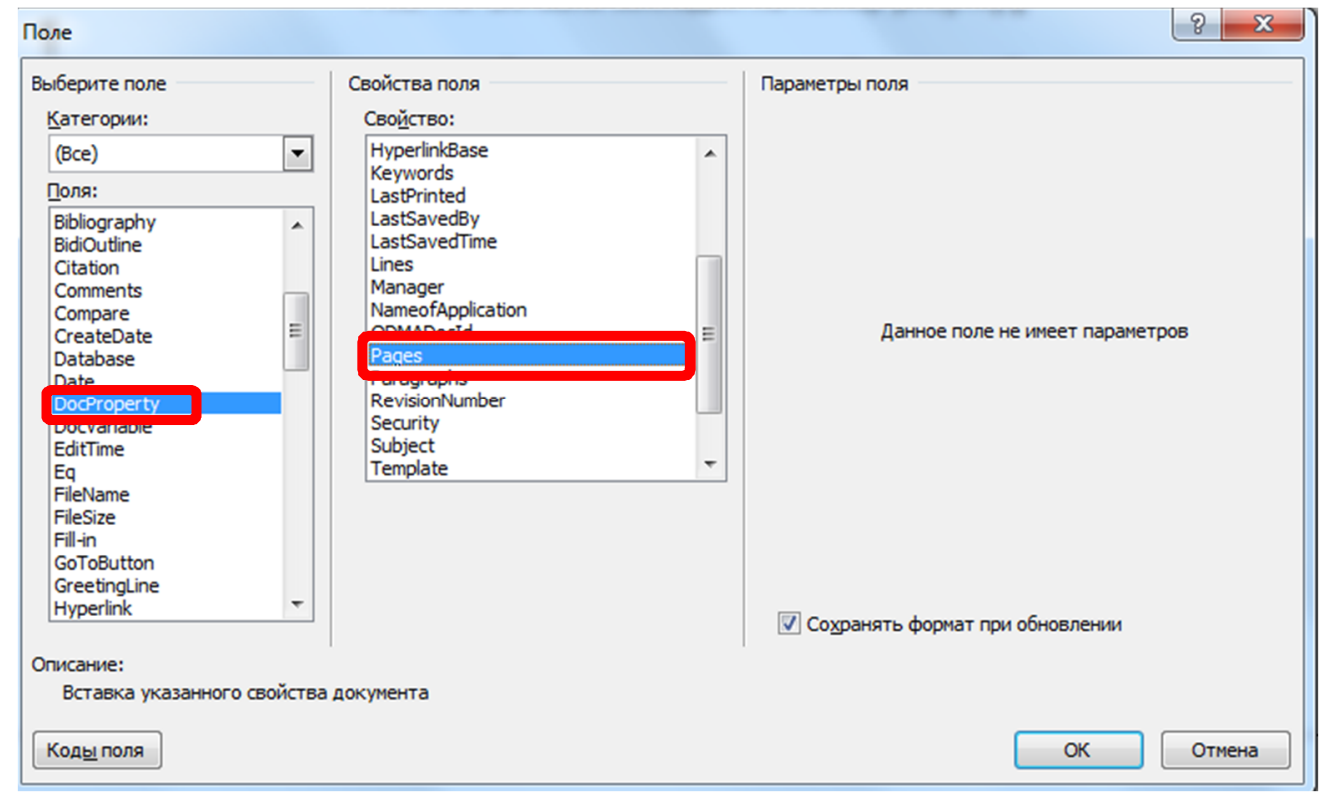

Рис. 17. Вставка поля

\section{IV Обговорення}

В розділі «Результати» наведені лише деякі приклади використання автоматичних елементів оформлення документів. В роботах [18-22] доведена важливість використання вказаних елементів для створення гнучкого при редагуванні, експорті та імпорті вмісту документа.

Для оволодіння навичками створення автоматизованих документів студенту також потрібен час. Наш досвід показує, достатньо 6 занять для оволодіння навичками використання всіх, перелічених у тематичному плані автоматичних елементів. Якщо для студентів інженерних спеціальностей такі навички важливі для підготування якісних технічних та наукових документів більшою частиною протягом навчання, то для студентів спеціальності, яких пов'язані із журналістикою або видавничою справою, ці навички являються одними із найважливіших серед «hard skills».

\section{V Висновки}

В результаті роботи:

1. Проаналізоване залучення студента до оформлення електронних документів. Виявлена суперечність між технічним оснащенням та навантаженням: при використанні програмних продуктів студенти на офрормлення результатів своєї діяльності витрачають більше часу, ніж при оформлені їх вручну.

2. Проаналізована готовність студентів до користування програмними продуктами доля оформлення електронних документів. Виявлено, що студентам притаманні низький рівень користувача програмних продуктів, та відсутність організаційного підходу при створенні документів.

3. У сучасному інформаційному просторі неможливо зовсім відмовитися від використання програмних продуктів при оформленні результатів діяльності студентів. Тому шляхом для вирішення суперечності, представленої у п. 1, ми вважаємо застосування системного підходу до навчання і набуття навичок у студентів при створенні електронних документів.

4. Створена методика дозволяє організувати та систематизувати навчання студентів. В результаті здобувачі засвоюють основні принципи роботи з автоматизованими документами.

Постає необхідність у розробці навчального посібника, який містив би практичні приклади використання автоматичних елементів при створенні документів при використанні різних програмних засобів. Також особливої уваги заслуговує навчання студентів принципам інфографріки: їі створення та використання. 


\section{Бібліографічні посилання}

1. Власюк А. І.. Белзецький Р. С. Основи редагування, коректури та верстки технічних текстів: навчальний посібник Вінниця: ВНТУ, 2015. 96 с.

2. Крайнікова Т. С. Коректура : підручник. К.: Наша культура і наука, 2005. 252 с.

3. Torres-Moreno Juan-Manuel. Evaluating Document Summaries. 2014. https://doi.org/10.1002/9781119004752.ch8

4. Torres-Moreno Juan-Manuel. Single-Document Summarization. 2014. https://doi.org/10.1002/9781119004752.ch3

5. Костенко Л. Й., Жабін О. І., Копанєва Є. О., Симоненко Т. В. Наукова періодика України та бібліометричні дослідження : монографрія. НАНУкраїни, Нац. б-ка України ім. В. І. Вернадського. К., 2014. 173 с.

6. Lin Xiaofan, Simske Steven J. Automatic document navigation for digital content remastering. Electronic Imaging. 2003. Volume 5296. Document Recognition and Retrieval XI. https://doi.org/10.1117/12.521991

7. Mital Dinesh P., Goh Wee Leng. Text segmentation for automatic document processing. Electronic Imaging. 1999. Volume 3651. Document Recognition and Retrieval VI. https://doi.org/10.1117/12.335819

8. Hendrickson Aidan, Pebay Philippe Pierre. Recommendations on a Document Structure Format for Automatic Report Generation. 2017. Sandia National Lab. (SNL-CA), Livermore, CA (United States). https://doi.org/10.2172/1376817

9. Котляров К. Г. Використання пакету Libre Office. Особливості та проблеми. Новітні інформаційно-комунікаційні технології в освіті (IICTE-2015). С. 52-53.

10. Пожидаєв І. Ю., Маляров М. В. Офісні пакети Microsoft Office та Libre Office: особливості, подібності, відмінності. Матеріали міжнародної НПК молодих учених НУЦЗУ. 2017. С. 235.

11. Горошко Ю. В., Костюченко А. О., Шкардибарда М. І. Проблеми та особливості впровадження вільного програмного забезпечення в навчальний процес. Комп'ютер у школі та сім'ї. 2010. №. 7. С. 8-10.

12. Стаття з бібліотеки Википедія, присвячена Офису 365. URL: https://ru.wikipedia.org/wiki/Microsoft_365

13. Лисенко С. М., Крищук А. Ф., Дзюбак Ю. П. Дослідження переваг застосування LATEX при оформленні наукових праць / Вісник Хмельницького національного університету. 2012. № 5. С. 225-234.

14. Гарасим Я. C., Романенко A. B., Хапко P. C. LaTeX: створення математичних документів: навчальний посібник. Львів: Видавничий центр ЛНУ імені Івана Франка, 2002. 140 с.

15. Oetiker Tobias, Partl Hubert, Hyna Irene, Schleg Elisabeth. The not so short introduction to LaTeX [Не надто короткий вступ

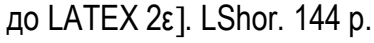

16. Власенко Д. І., Курінний Г. Ч. Вступ до видавничої системи LaTeX. Харківський національний університет імені B.H. Каразіна. Секція геометрії. 98 с. URL: http://ekhnuir.univer.kharkov.ua/handle/123456789/10639

17. Махней O. В. Практикум з LaTeX : методичні рекомендації. Івано-Франківськ: Голіней, 2018. 36 с.

18. Hauptmann A. Spoken Document Retrieval, Automatic. https://doi.org/10.1016/B0-08-044854-2/00922-6

19. Mussina Aigerim, Aubakirov Sanzhar, Trigo Paulo. Automatic Document Summarization based on Statistical Information. Proceedings of the 7th International Conference on Data Science, Technology and Applications. 2018. PP. 71-76. DOI: 10.5220/0006888400710076

20. Moens Marie-Francine. Automatic Indexing and Abstracting of Document Texts. https://doi.org/10.1016/B0-08-0448542/00958-5

21. Chen Su, Haralick R. M.; Phillips I. T. Automatic text skew estimation in document images. IEEE. https://ieeexplore.ieee.org/document/602126

22. Hassan Tamir, Hunter Andrew. Knuth-Plass Revisited: Flexible Line-Breaking for Automatic Document Layout. Proceedings of the 2015 ACM Symposium on Document Engineering. September 2015. PP. 17-20. https://doi.org/10.1145/2682571.2797091

\section{References}

1. Vlasiuk, A. I., Belzetskyi, R. S. (2015). Osnovy redahuvannia, korektury ta verstky tekhnichnykh tekstiv: navchalnyi posibnyk VNTU, Vinnytsia, 96.

2. Krainikova, T. S. (2005). Korektura : pidruchnyk. Nasha kultura i nauka, Kyiv, 252.

3. Torres-Moreno, J.-M. (2014). Evaluating Document Summaries. doi: https://doi.org/10.1002/9781119004752.ch8

4. Torres-Moreno, J.-M. (2014). Single-Document Summarization. doi: https://doi.org/10.1002/9781119004752.ch3

5. Kostenko, L. Y., Zhabin, O. I., Kopanieva, Ye. O., Symonenko, T. V. (2014). Naukova periodyka Ukrainy ta bibliometrychni doslidzhennia : monohrafiia. NANUkrainy, Nats. b-ka Ukrainy im. V. I. Vernadskoho, Kyiv, 173.

6. Lin, X., Simske, S. J. (2003). Automatic document navigation for digital content remastering. Electronic Imaging, 5296, Document Recognition and Retrieval XI. doi: https://doi.org/10.1117/12.521991

7. Mital, D. P., Goh, W. L. (1999). Text segmentation for automatic document processing. Electronic Imaging, 3651,. Document Recognition and Retrieval VI. doi: https://doi.org/10.1117/12.335819

8. Hendrickson, A., Pebay, Ph. P. (2017). Recommendations on a Document Structure Format for Automatic Report Generation. Sandia National Lab. (SNL-CA), Livermore, CA (United States). doi: https://doi.org/10.2172/1376817

9. Kotliarov, K. H. (2015). Vykorystannia paketu Libre Office. Osoblyvosti ta problemy. Novitni informatsiino-komunikatsiini tekhnolohii v osviti (IICTE-2015), 52-53.

10. Pozhydaiev, I. Yu., Maliarov, M. V. (2017). Ofisni pakety Microsoft Office ta Libre Office: osoblyvosti, podibnosti, vidminnosti. Materialy mizhnarodnoi NPK molodykh uchenykh NUTsZU, 235. 
11. Horoshko, Yu. V., Kostiuchenko, A. O., Shkardybarda. M. I. (2010). Problemy ta osoblyvosti vprovadzhennia vilnoho prohramnoho zabezpechennia v navchalnyi protses. Kompiuter u shkoli ta simi, №. 7, 8-10.

12. Wikipedia article on Office 365. URL: https://ru.wikipedia.org/wiki/Microsoft_365 (accessed 10.08.2020)

13. Lysenko, S. M., Kryshchuk, A. F., Dziubak, Yu. P. (2012). Doslidzhennia perevah zastosuvannia LATEX pry oformlenni naukovykh prats. Visnyk Khmelnytskoho natsionalnoho universytetu, № 5, 225-234.

14. Harasym, Ya. S., Romanenko, A. V., Khapko, R. S. (2002). LaTeX: stvorennia matematychnykh dokumentiv: navchalnyi posibnyk. Lviv: Vydavnychyi tsentr LNU imeni Ivana Franka, 140.

15. Oetiker, T., Partl, H., Hyna, I., Schleg, E. (1995). The not so short introduction to LaTeX (Не надто короткий вступ до LATEX $2 \varepsilon)$. LShor. 144 p.

16. Vlasenko, D. I., Kurinnyi, H. Ch. (2000). Vstup do vydavnychoi systemy LaTeX. Kharkivskyi natsionalnyi universytet imeni V.N. Karazina, Sektsiia heometrii, 98. URL: http://ekhnuir.univer.kharkov.ua/handle/123456789/10639 (accessed 10.08.2020).

17. Makhnei, O. V. (2018). Praktykum z LaTeX: metodychni rekomendatsii. Holinei, Ivano-Frankivsk, 36.

18. Hauptmann, A. (2006). Spoken Document Retrieval, Automatic. doi: https://doi.org/10.1016/B0-08-044854-2/00922-6

19. Mussina, A., Aubakirov, S., Trigo, P. (2018). Automatic Document Summarization based on Statistical Information. Proceedings of the 7th International Conference on Data Science, Technology and Applications, 71-76. doi: 10.5220/0006888400710076

20. Moens M.-F. (2001). Automatic Indexing and Abstracting of Document Texts. doi: https://doi.org/10.1016/B0-08-0448542/00958-5

21. Chen, Su, Haralick, R. M.; Phillips, I. T. (1995). Automatic text skew estimation in document images. IEEE. URL: https:/lieeexplore.ieee.org/document/602126 (accessed 10.08.2020).

22. Hassan, T., Hunter, A. (2015). Knuth-Plass Revisited: Flexible Line-Breaking for Automatic Document Layout. Proceedings of the 2015 ACM Symposium on Document Engineering, 17-20. doi: https://doi.org/10.1145/2682571.2797091

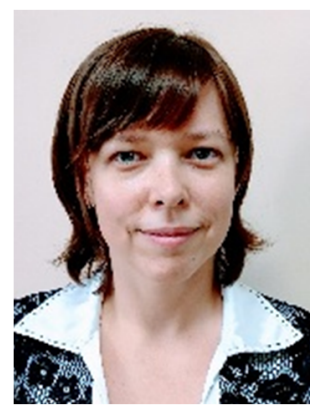

\section{Істоміна Наталія Миколаївна.}

старший викладач кафедри «Автоматизація та інформаційні системи», Кременчуцький національний університет імені Михайла Остроградського, вул. Першотравнева, 20, м. Кременчук Полтавської обл., Україна, 39600. Тел. +38(05366) 3-11-47. E-mail: nmistomina@gmail.com

\section{Istomina Nataliia Mykolaivna.}

Senior Lecturer of Information and Control Systems Department,

Kremenchuk Mykhailo Ostrohradskyi National University,

vul. Pershotravneva, 20, Kremenchuk, Poltava Region, Ukraine, 39600.

Tel. +38(05366) 3-11-47. E-mail: nmistomina@gmail.com

ORCID: 0000-0002-6811-8115

Scopus ID: 57210290054

\section{Citation (APA):}

Istomina, N. (2020). Designing the training students methods of automated documents creation. Engineering and Educational Technologies, 8 (3), 58-71. doi: https://doi.org/10.30929/2307-9770.2020.08.03.05

\section{Цитування (ДСТУ 8302:2015):}

Істоміна Н. М. Розробка методики навчання студентів створенню автоматизованих документів / Інженерні та освітні технології. 2020. Т. 8. № 3. С. 58-71. doi: https://doi.org/10.30929/2307-9770.2020.08.03.05

Обсяг статmі: сторінок-14 ; умовних друк. аркушів - 2,028. 